\title{
ДОСВІД ВПРОВАДЖЕННЯ ПРИНЦИПІВ ДОКАЗОВОЇ МЕДИЦИНИ В НАВЧАЛЬНИЙ ПРОЦЕС НА КАФЕДРІ АКУШЕРСТВА І ГІНЕКОЛОГІЇ № 1 ОДЕСЬКОГО НАЦІОНАЛЬНОГО МЕДИЧНОГО УНІВЕРСИТЕТУ
}

\author{
В. М. Запорожан, В. Г. Марічереда, А. Г. Волянська, С. А. Полякова \\ Одеський наиіональний медичний університет
}

\section{EXPERIENCE OF PRINCIPLES EVIDENCE-BASED MEDICINE IN THE TRAINING PROCESS AT THE DEPARTMENT OF OBSTETRICS AND GYNECOLOGY №1 OF ODESSA NATIONAL MEDICAL UNIVERSITY}

\author{
V. M. Zaporozhan, V. H. Marichereda, A. H. Volyanska, Ye. A. Polyakova \\ Odessa National Medical University
}

\begin{abstract}
У статті висвітлено досвід впровадження методів доказової медицини в лекційний курс та методику практичних занять у лікарів і студентів 4 - 6 року навчання. Знання результатів рандомізованих досліджень методів лікування розширює кругозір лікаря у його лікарській практиці.

The experience of introduction of evidence-based medicine methods in the lecture course and technique of practical training at doctors and students 4-6 year studying is adduced in the article. The knowledge of results of randomized researches of treatment methods expands an outlook of the doctor in medical practice.
\end{abstract}

Вступ. В середовищі кваліфікованих фахівців немає сумнівів в ефективності використання методів лікування хворих, що засновані на результатах міжнародних багатоцентрових контрольованих досліджень [1]. Останні, здавалося б, повинні швидко привести до повсюдного їх впровадження у лікувальну практику. Проте, насправді, це не відбувається внаслідок впливу “традиційного консерватизму” й інерційного мислення лікаря [2]. Подолати консерватизм можна тільки шляхом тривалої наполегливої роботи за допомогою ясних і зрозумілих аргументів, опублікованих у доступній літературі. Однак найефективнішою ми вважаємо роботу в контакті з лікарями і студентами, які більшою мірою сприйнятливі до нових поглядів.

Основна частина. 3 метою ознайомлення студентів IV, V, VI курсів та лікарів (на тематичних і передатестаційних циклах) 3 методами доказової медицини в лекційний курс та тематику практичних занять ми включаємо матеріали багатоцентрових контрольованих досліджень, що проводяться на кафедрі, наприклад, проект з виявлення генетичних аспектів вродженої патології нервової системи, зокрема дефектів нервової трубки (ВДНТ), який виконується спільно з відділенням цитогенетики Istituti Ospitalieri Di Cremona (Італія) у рамках дослідження
Prevention of Neural Tube Defects by Inositol in Conjunction With Folic Acid (PONTI Study) NCT00452829; та у співпраці з почесним доктором ОДМУ, деканом медичного факультету, завідувачем кафедри мікробіології і вірусології Болонського університету (Італія), професором Марією Паолою Ландіна, виконується етап європейської програми з вивчення перинатальної трансмісії цитомегаловірусної інфекції та генотипування вірусу на території Півдня України.

При цьому слід врахувати, що участь у навчальному процесі викладачів, які $є$ виконавцями досліджень, підвищує ефективність занять. Для осмислення і розуміння суті, а значить і міри доведеності результатів рандомізованих досліджень на практичних заняттях викладач пояснює методологію цього процесу.

При розробці теми до відома студентів та курсантів викладач доводить таке [3].

1. Вимоги Good Clinical Practice (GCP) (надійної клінічної практики), згідно з якою клінічні випробування слід проводити в інтересах хворих з дотриманням високих етичних стандартів (пацієнти отримують повну інформацію про препарат).

Протокол дослідження повинен бути оформлений регіональним етичним комітетом.

(C) В. М. Запорожан, В. Г. Марічереда, А. Г. Волянська, Є. А. Полякова 
Необхідно отримати інформовану згоду пацієнта в письмовій формі.

2. Ретельне заповнення на кожного хворого Case Report Form (CRF) (медичного звіту).

3. Високий науково-методичний рівень протоколу.

4. Ретельний відбір хворих. Наявність контрольного періоду (пацієнт не приймає препарати), використання плацебо, коректна рандомізація.

5. Суть відкритого, простого сліпого або подвійного сліпого методів дослідження.

6. Поняття про сучасні математичні методи медичної статистики.

Необхідність знання різних критеріїв оцінки результатів захворювання за “кінцевими точками” очевидна. Важливим також $є$ і доведення до відома учнів градацій і рівнів доказів Evidence Based Medicine (медицина, заснована на доказах) $[4,5]$. Так, студенти та курсанти повинні знати, що градація А складається $з$ чотирьох рівнів. Рівень $1 \mathrm{a}-$ докази, що засновані на даних великих рандомізованих клінічних досліджень або спеціальних оглядів (які включають мета-аналізи) великого числа рандомізованих досліджень, 3 яких хоча б в одному наведено методично суворий опис отриманих даних [6].

Рівень 16 - докази, засновані на даних щонайменше одного дослідження високої якості з оцінкою результатів лікування за принципом “все або нічого”.

\section{Лiтература}

1. Власов В. В. Введение в доказательную медицину / В. В. Власов. - М. : Медиа Сфера, 2001.-392 с.

2. Поляков А. Є. Впровадження принципів доказової медицини в підготовку лікаря загальної практики / А. С. Поляков., Л. Ковальчук, С. Андрієвська // Вища школа. -2008. - № 3. - С. 49-52.

3. Планирование и проведение клинических исследований лекарственных средств / под ред. Ю. Б. Белоусова. М. : ООО "Изд-во Общества клинических исследователей”, 2000.-579 с.

4. Ступаков И. Н. Рандомизированные исследования : проблемы и перспективы / И. Н.Ступаков, И. В. Самород-
Рівень 1в - докази, засновані на даних щонайменше одного дослідження середнього масштабу або даних мета-аналізу ряду малих досліджень.

Рівень 1г - докази, засновані на даних одного дослідження.

Градієнт Б складається з трьох послідовних рівнів.

Рівень 2 - докази, засновані на даних одного дослідження високої якості, але в якому хворі не були рандомізовані - основна група та група порівняння.

Рівень 3 - докази, засновані на даних одного дослідження високої якості, в якому була група порівняння.

Рівень 4 - докази, засновані на даних одного дослідження високої якості.

Градієнт В - включає рівень 5 - думки експертів без посилань на джерела.

Зазначені градації та рівні не можуть повністю відобразити всерізноманіття результатів дослідження [7].

Висновки. На закінчення необхідно відзначити, що практикуючий лікар зобов' язаний знати про результати рандомізованих досліджень методів лікування, використовуваних ним у лікувальній практиці, особливо у випадках, коли мають місце протипоказання до застосування цих засобів.

Без урахування результатів клінічних випробувань в дослідницькій роботі на сучасному рівні лікар не може планувати іздійснювати дослідження.

ская // Бюлл. НЦССХ им. А. Н. Бакулева РАМН. - 2001. T. 2, № 5. - C. 12-15.

5. Флетчер Р. Клиническая эпидемиология. Основы доказательной медицины / Р. Флетчер, С. Флетчер, Э. Вагнер; пер. с англ. - М. : Медиа Сфера, 1998. - 352 c.

6. The design of randomized clinical trials in critically ill patients / Hubert P. C., Cook D. J., Wells G., Marshall J. // Chest. -2002. - Vol. 121. - P. 1290-1300.

7. Recombinant human activated protein $\mathrm{C}$, drotrecogin alfa (activated): A novel therapy for severe sepsis / Kanji S., Devlin J. W., Piekos R. A., Racine E. // Pharmacotherapy. 2001. - Vol. 21, № 11.-P. 1389-1402. 